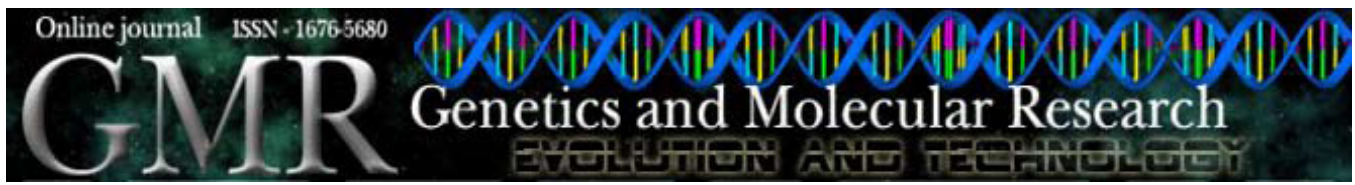

\title{
Genetic diversity of eggplant (Solanum melongena) germplasm from Turkey assessed by SSR and RAPD markers
}

\author{
K. Demir ${ }^{1}$, M. Bakır ${ }^{2}$, G. Sarıkamış ${ }^{1}$ and S. Acunalp ${ }^{2}$ \\ ${ }^{1}$ Department of Horticulture, Faculty of Agriculture, \\ Ankara University, Ankara, Turkey \\ ${ }^{2}$ Biotechnology Institute, Ankara University, Ankara, Turkey \\ Corresponding author: K. Demir \\ E-mail: koksaldem@ankara.edu.tr
}

Genet. Mol. Res. 9 (3): 1568-1576 (2010)

Received May 13, 2010

Accepted June 30, 2010

Published August 10, 2010

DOI 10.4238/vol9-3gmr878

\begin{abstract}
Eggplant is a major crop in Turkey, which produces more of this crop than all of Europe; consequently, germplasm resources are of concern for the country. Molecular characterization of eggplant genotypes collected from different geographical regions of Turkey was carried out using SSR and RAPD markers. With amplification of five SSR loci, the number of alleles per microsatellite locus ranged from 2 to 10 , with a total of 24 alleles. The greatest number of alleles was found at the emf21H22 locus (10 alleles); followed by emh11O01 and emf $21 \mathrm{Cl1}$ as five and four alleles, respectively. The average number of alleles per locus was 4.8. Using 11 decamer RAPD primers, 100 bands were amplified, among which 29 were polymorphic. The number of bands per primer ranged from seven $(\mathrm{OPH} 10, \mathrm{OPH} 19, \mathrm{OPH} 20$, $O P H 03)$ to 14 (OPB07). Primer OPB07 was the most polymorphic, generating $64 \%$ polymorphic bands; the rest of the primers gave less than $50 \%$ polymorphism. UPGMA dendrograms were used to examine the genetic relatedness of the genotypes.
\end{abstract}

Key words: Eggplant; Solanum melongena; SSR; RAPD; Genetic resources 


\section{INTRODUCTION}

Eggplant, Solanum melongena L., is a member of the Solanaceae family grown extensively in central, southern and southeast Asia and in a number of African countries (Kalloo, 1993). It is a good source of minerals and vitamins, like other prominent solanaceous vegetables such as tomato, and hence, it is important for human nutrition. The consumption of fruits and vegetables is important for the prevention of several diseases, and there is growing interest among consumers in the health benefits of foods. Several studies report approaches to minimize losses and maintain nutritional value in fruits and vegetables (Özkaya and Dündar, 2009a,b).

Eggplant is grown on 1,957,603 hectares, with a total production of 32,699,078 tonnes (FAO, 2008). As the fourth leading eggplant producer after China, India and Egypt, Turkey is an important eggplant producer with an annual production of 813,686 tonnes (FAO, 2008).

The evaluation of genetic resources is crucial for breeders to produce new cultivars or to further improve the existing ones, according to changing consumer demands or challenges during growth conditions such as resistance attributes. So far, eggplant genotypes have been collected only in some European and Asian countries, but there is no comprehensive collection dedicated to the germplasm of eggplants available worldwide. It has been reported that gene banks for eggplant and related species have been generated by the EGGNET project in Europe (http://www.bgard.science.ru.nl/eggnet/eggnet01.html). In Turkey, eggplant genotypes collected from different geographical regions of Turkey are maintained at the Aegean Agricultural Research Institute of the Ministry of Agricultural and Rural Affairs.

The analysis of genotypes derived from different geographical areas is important to study genetic diversity. In order to assess genetic diversity as well as to discriminate eggplant cultivars and related Solanum species, morphological and biochemical (isozymes and chromatography) approaches were used (Weijun, 1992; Isshiki et al., 1994). On the other hand, molecular markers have enormous potential to explore genetic diversity by detecting polymorphisms. They are useful tools for breeding, genotype identification, and the determination of genome organization and evolution in plants. However, despite its widespread cultivation and nutritional and economic importance, the eggplant genome has not yet been extensively evaluated as for the other solanaceous vegetables such as tomato, potato and pepper. Few studies have been performed to determine the genetic diversity of eggplant using random amplified polymorphic DNA (RAPD) (Nunome et al., 2001), AFLP (Mace et al., 1999), RAPD and AFLP (Nunome et al., 2001), simple sequence repeats (SSR) (Nunome et al., 2003; Stàgel et al., 2008; Nunome et al., 2009), and ISSR (Isshiki et al., 2008). A comparative genetic linkage map based on tomato cDNA, genomic DNA, and expressed sequence tag (EST) markers was constructed for eggplant (Doğanlar et al., 2002).

During recent decades, SSR also known as microsatellites have become the most popular source of genetic markers owing to their high reproducibility, multi-allelic nature, co-dominant inheritance, abundance, and wide genome coverage. SSR markers have been successfully adopted to analyze genetic diversity in a variety of different plant species (He et al., 2003; Frary et al., 2005; Sarıkamış et al., 2006, 2009, 2010). It was long assumed that SSRs were primarily associated with non-coding DNA, but it is now clear that they are also abundant in the single- and lowcopy fraction of the genome commonly referred to as genic SSRs or EST-SSRs. A number of SSR markers have been identified in Solanaceae (Yi et al., 2006; Bindler et al., 2007), but not many are developed from eggplant. The development of SSR markers derived from SSR-enriched genomic 
library of eggplant was reported by Nunome et al. (2003, 2009). More recently, in silico mining of microsatellite sequences from DNA-sequence databases has been an alternative for obtaining microsatellite markers from genomic libraries (Stàgel et al., 2008).

On the other hand, RAPD markers provide a rapid, inexpensive and effective system for studying plant genetic relationships. They are particularly suitable for less well-known species because they can be applied without prior knowledge of DNA sequence information. Since 1990, the RAPD technique has been extensively used in plant systematic studies, especially in the identification of germplasm resources and the measurement of variation to establish evolutionary relationships within or between species, subspecies or populations and genomes. While RAPD markers are considered to be dominant markers, it has been shown that RAPD markers can be efficient in estimating genetic diversity and in analyzing genetic relationships. RAPD markers were also efficiently used for the molecular characterization of eggplant (Nunome et al., 2001). Moreover, the combined use of different marker systems may provide more reliable information about genetic diversity when compared to the use of only one marker system so that some errors or problems occurring with the use of a certain marker system could be minimized when combined (Saker et al., 2005; Leal et al., 2010).

The aim of the present study was to characterize eggplant genotypes collected from different geographical regions of Turkey using SSR and RAPD markers and to assess the genetic diversity within this germplasm. Assessment of genetic diversity is important for breeding purposes, and the utilization of molecular markers helps accelerate the evaluation process.

\section{MATERIAL AND METHODS}

\section{Plant material}

The germplasm used in this study consisted of 19 eggplant (Solanum melongena L.) genotypes obtained from the Gene Bank of the Aegean Agricultural Research Institute of the Turkish Ministry of Agricultural and Rural Affairs. The collection site of each eggplant genotype is shown in Table 1. Commercial cultivar, Kemer 59, was used as reference cultivar during the molecular analysis.

\begin{tabular}{|c|c|c|c|}
\hline Genotype & Record No. & Botanical name & Collection site \\
\hline 1 & TR 77295 & Solanum melongena & Tekirdağ \\
\hline 2 & TR 77307 & Solanum melongena & Edirne \\
\hline 3 & TR 47832 & Solanum melongena & Adiyaman \\
\hline 4 & TR 61540 & Solanum melongena & Aydin \\
\hline 5 & TR 61892 & Solanum melongena & Denizli \\
\hline 6 & TR 62581 & Solanum melongena & Balıkesir \\
\hline 7 & TR 62668 & Solanum melongena & Manisa \\
\hline 8 & TR 62776 & Solanum melongena & İzmir \\
\hline 9 & TR 66559 & Solanum melongena & Kütahya \\
\hline 10 & TR 66009 & Solanum melongena & Eskișehir \\
\hline 11 & TR 66018 & Solanum melongena & Bilecik \\
\hline 12 & TR 66015 & Solanum melongena & Bursa \\
\hline 13 & TR 43010 & Solanum melongena & Çanakkale \\
\hline 14 & TR 66672 & Solanum melongena & Isparta \\
\hline 15 & TR 66695 & Solanum melongena & Burdur \\
\hline 16 & TR 72585 & Solanum melongena & Mersin \\
\hline 17 & TR 75343 & Solanum melongena & Erzurum \\
\hline 18 & TR 75345 & Solanum melongena & Artvin \\
\hline 19 & TR 37395 & Solanum melongena & Çorum \\
\hline 20 & Kemer 59 & Solanum melongena & Reference cultivar \\
\hline
\end{tabular}




\section{Molecular characterization}

\section{DNA extraction}

Genomic DNA was extracted from young leaf tissue following the procedure given by Lefort et al. (1998). DNA quality and quantity were assessed on a $1 \%(\mathrm{w} / \mathrm{v})$ agarose gel stained with ethidium bromide and also by using a NanoDrop ${ }^{\circledR}$ ND-1000 spectrophotometer.

\section{SSR analysis}

Five eggplant SSRs were selected to detect polymorphisms and assess genetic diversity of the germplasm. The selection of five eggplant SSRs was based on their high polymorphism information content and the quality scores reported (Nunome et al., 2009).

The polymerase chain reaction (PCR) mixture contained $15 \mathrm{ng}$ DNA, 5 pmol of each primer, $0.5 \mathrm{mM}$ dNTP, $0.5 \mathrm{U}_{\text {GoTaq DNA polymerase (Promega }}{ }^{\circledR}$, Madison, WI, USA), $1.5 \mathrm{mM} \mathrm{MgCl}, 2 \mu \mathrm{L} 5 \mathrm{X}$ buffer in a volume of $10 \mu \mathrm{L}$. The forward primers were labeled with WellRED fluorescent dyes D2 (black), D3 (green) and D4 (blue) (Sigma). Reaction mixtures without DNA were included as negative controls. PCR amplification was performed using the Biometra ${ }^{\circledR}$ PCR System. The amplification conditions involved an initial step of $3 \mathrm{~min}$ at $94^{\circ} \mathrm{C}$, followed by 35 cycles of $1 \mathrm{~min}$ at $94^{\circ} \mathrm{C}, 1 \mathrm{~min}$ at $60-66^{\circ} \mathrm{C}$ and $2 \mathrm{~min}$ at $72^{\circ} \mathrm{C}$, with a final extension at $72^{\circ} \mathrm{C}$ for $10 \mathrm{~min}$. PCR products were diluted with sample loading solution in certain proportions according to the fluorescent dyes used in labeling, followed by the addition of the Genomelab DNA Standard Kit-400 and electrophoresed in the CEQ 8800XL capillary DNA analysis system (Beckman Coulter, Fullerton, CA, USA). The analyses were repeated at least twice to ensure reproducibility of the results. Allele sizes were determined for each SSR locus using the Beckman CEQ fragment analysis software.

\section{RAPD analysis}

A total of 11 decamer primers were used for RAPD analysis. Amplification was performed in a $25-\mu \mathrm{L}$ reaction volume containing $200 \mathrm{ng}$ genomic DNA, $2.5 \mu \mathrm{L} 10 \mathrm{X}$ reaction buffer, $3.5 \mu \mathrm{L} 25 \mathrm{mM} \mathrm{MgCl}_{2}, 2 \mu \mathrm{L} 2.5 \mathrm{mM}$ dNTPs, $200 \mathrm{ng}$ primer and $0.5 \mathrm{U}$ Taq polymerase $\left(\right.$ Promega $^{\circledR}$ ). The PCR program was started with an initial cycle of $94^{\circ} \mathrm{C}$ for 5 min followed by 35 cycles of $30 \mathrm{~s}$ at $94^{\circ} \mathrm{C}, 1 \mathrm{~min}$ at $35^{\circ} \mathrm{C}$ and $1 \mathrm{~min} 45 \mathrm{~s}$ at $72^{\circ} \mathrm{C}$. Finally, extension was performed at $72^{\circ} \mathrm{C}$ for $8 \mathrm{~min}$.

\section{Genetic analysis}

The genetic analysis "IDENTITY" 1.0 program (Wagner and Sefc, 1999) according to Paetkau et al. (1995) was used for calculating the number of alleles, allele frequency, expected and observed heterozygosity, estimated frequency of null alleles (r), and probability of identity per locus. Genetic dissimilarity was determined by the "MICROSAT" program (version 1.5) (Minch et al., 1995), using proportion of shared alleles, which was calculated using ps (option 1 - (ps)) as described by Bowcock et al. (1994). 
The results were then converted to a similarity matrix and a dendogram was constructed with UPGMA (unweighted pair-group method with arithmetic mean) (Sneath and Sokal, 1973), using the NTSYS-pc software (Numerical Taxonomy and Multiware Analysis System) (Version 2.0) (Rohlf, 1988).

\section{RESULTS}

Microsatellite markers selected on the basis of high polymorphism information content revealed successful amplifications of expected allele sizes (Table 2). According to the amplification of five SSR loci, the number of alleles per microsatellite locus of the 19 genotypes ranged from 2 to10, comprising a total of 24 alleles. The greatest number of alleles was found at the emf $21 H 22$ comprising 10 alleles, and at the emh11O01 and emf $21 \mathrm{C} 11$ loci, comprising 5 and 4 alleles, respectively. The average number of alleles per locus was 4.8 . Heterozygosity for individual loci in eggplant genotypes ranged from 0.00 to 0.85 . Probability of identity values were generally greater than 0.05 , estimated according to Sefc et al. (2001). The estimated frequency of null alleles was high except at the emf $21 \mathrm{H} 22$ locus where observed heterozygosity was higher than expected heterozygosity.

\begin{tabular}{|c|c|c|c|c|c|c|c|c|c|c|}
\hline \multirow{2}{*}{$\frac{\text { Genotype }}{1}$} & \multicolumn{2}{|c|}{ emh11001 } & \multicolumn{2}{|c|}{ embO1H2O } & \multicolumn{2}{|c|}{ emb01L13 } & \multicolumn{2}{|c|}{ emf $21 H 22$} & \multicolumn{2}{|c|}{ emf $21 C 11$} \\
\hline & 228 & 228 & 354 & 354 & 169 & 169 & 100 & 100 & 202 & 202 \\
\hline 2 & 226 & 226 & 350 & 350 & 169 & 169 & 102 & 112 & 202 & 202 \\
\hline 3 & 222 & 222 & 352 & 352 & 169 & 169 & 102 & 124 & 202 & 202 \\
\hline 4 & 228 & 228 & 352 & 352 & 169 & 169 & 102 & 132 & 202 & 202 \\
\hline 5 & 228 & 228 & 352 & 352 & 169 & 169 & 106 & 132 & 202 & 202 \\
\hline 6 & 224 & 224 & 350 & 350 & 169 & 169 & 104 & 132 & 200 & 200 \\
\hline 7 & 218 & 228 & 352 & 352 & 169 & 169 & 104 & 130 & 202 & 202 \\
\hline 8 & 226 & 226 & 352 & 352 & 169 & 169 & 102 & 132 & 200 & 200 \\
\hline 9 & 226 & 226 & 350 & 350 & 167 & 167 & 104 & 134 & 202 & 202 \\
\hline 10 & 222 & 222 & 352 & 352 & 169 & 169 & 104 & 134 & 202 & 202 \\
\hline 11 & 226 & 226 & 350 & 350 & 169 & 169 & 104 & 134 & 202 & 202 \\
\hline 12 & 218 & 218 & 352 & 352 & 169 & 169 & 104 & 134 & 202 & 202 \\
\hline 13 & 226 & 226 & 352 & 352 & 167 & 167 & 102 & 134 & 204 & 204 \\
\hline 14 & 218 & 218 & 352 & 352 & 169 & 169 & 102 & 128 & 200 & 200 \\
\hline 15 & 218 & 218 & 352 & 352 & 169 & 169 & 102 & 132 & 202 & 202 \\
\hline 16 & 224 & 224 & 352 & 352 & 169 & 169 & 128 & 128 & 198 & 198 \\
\hline 17 & 224 & 224 & 354 & 354 & 169 & 169 & 104 & 134 & 202 & 202 \\
\hline 18 & 224 & 224 & 352 & 352 & 169 & 169 & 102 & 132 & 204 & 204 \\
\hline 19 & 224 & 224 & 350 & 354 & 169 & 169 & 102 & 132 & 202 & 202 \\
\hline 20 & 224 & 224 & 352 & 352 & 169 & 169 & 134 & 134 & 202 & 202 \\
\hline
\end{tabular}

Genetic similarity among genotypes was scaled between 0.15 and 1 . The UPGMA dendrogram as defined by SSR markers revealed two major groups (Figure 1). The first group (Group 1) included the genotypes named 2, 11, 9, and 13, and the second group included the remaining genotypes as well as the reference cultivar Kemer 59. Subsequently, Group 2 was further divided into several subgroups containing the remaining genotypes and cultivars. In this group, 4 and 5 showed a high genetic similarity (0.91) followed by 3 and 10, 7 and 12 $(0.81)$. The genotypes 2 and 11, which grouped separately, also revealed a high genetic similarity (0.81). Genotypes 17 and 19 grouped closely with the reference cultivar Kemer 59. 


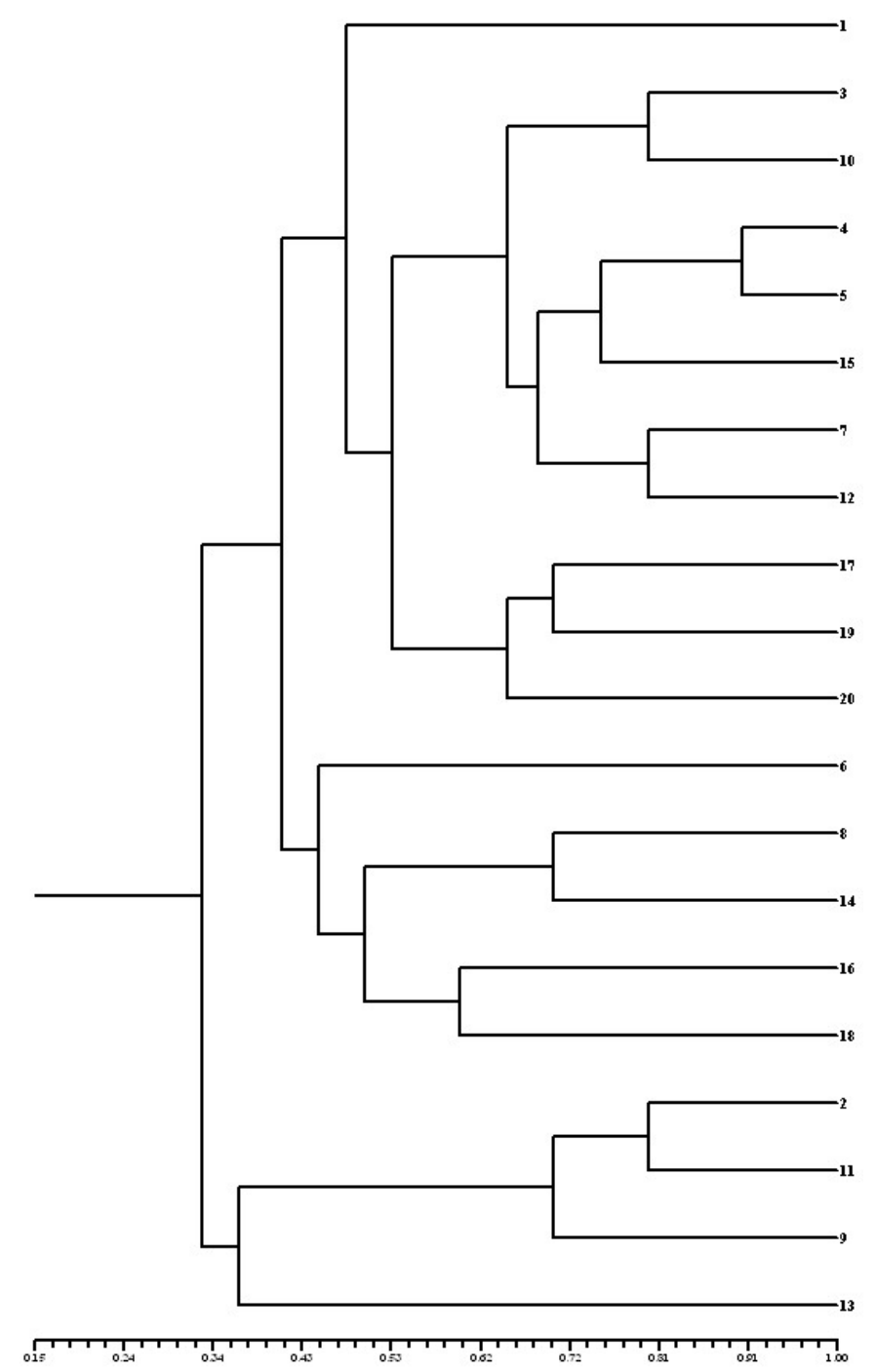

Figure 1. Dendrogram showing the genetic relatedness of 19 eggplant genotypes together with a commercial eggplant cultivar (20) based on the UPGMA cluster analysis of five simple sequence repeat marker data.

Of the 11 decamer primers tested, a total of 100 bands were amplified among which 29 bands were polymorphic (Table 3). The number of bands for each primer varied from 7 (OPH10, OPH19, OPH20, OPH03) to 14 (OPBO7) with an average of 9.1 bands per primer. The primer $O P B 07$ was the most polymorphic among all primers tested, generating $64.2 \%$ polymorphic bands, while the rest of the primers (OPH10, OPO10, OPH19, OPBO8, OPH13, OPLO4, OPH02, OPH03, and OPL16) displayed less than 50\% polymorphism. One primer $(\mathrm{OPH} 2 \mathrm{O})$ produced a monomorphic band pattern for all genotypes (Table 3). 
Table 3. Total number of bands and percentage of polymorphic bands obtained by amplifying each genotype with random amplified polymorphic DNA (RAPD) primers.

\begin{tabular}{llcc}
\hline RAPD primer & Sequence (5'-3') & Total bands & Polymorphic bands (\%) \\
\hline OPH10 & CCTACGTCAG & 7 & $2(28.5 \%)$ \\
OPO10 & TCAGAGCGCC & 9 & $3(33.3 \%)$ \\
OPH19 & CTGACCAGCC & 7 & $1(14.2 \%)$ \\
OPH20 & GGGAGACATC & 7 & - \\
OPBO8 & GTCCACACGG & 1 & $1(12.5 \%)$ \\
OPH13 & GACGCCACAC & 11 & $1(9.09 \%)$ \\
OPLO4 & GACTGCACAC & 12 & $4(33.3 \%)$ \\
OPH02 & TCGGACGTGA & 7 & $4(40 \%)$ \\
OPH03 & AGACGTCCAC & 14 & $2(28.5 \%)$ \\
OPBO7 & GGTGACGCAG & 8 & $9(64.2 \%)$ \\
OPL16 & AGGTTGCAGG & $2(25 \%)$ \\
\hline
\end{tabular}

Two major groups were determined according to cluster analysis (Figure 2). A single genotype (16) clustered separately from the remaining genotypes, and the reference cultivar formed a single group (Group 1). The larger cluster (Group 2) consisted of the rest of the genotypes and the reference cultivar. Within the large group (Group 2), a single genotype (11) grouped separately from the rest of the genotypes; however, the overall genetic similarity was very high (0.9) in general. While genotypes 5 and 8 were identical, genotype 2 was closely related to 5 and 8 (0.988), and genotype 9 was closely related to $2(0.975)$ and 5 and $8(0.988)$ according to the UPGMA analysis based on RAPD band patterns. The reference cultivar (Kemer 59) formed a separate sub-group on its own.

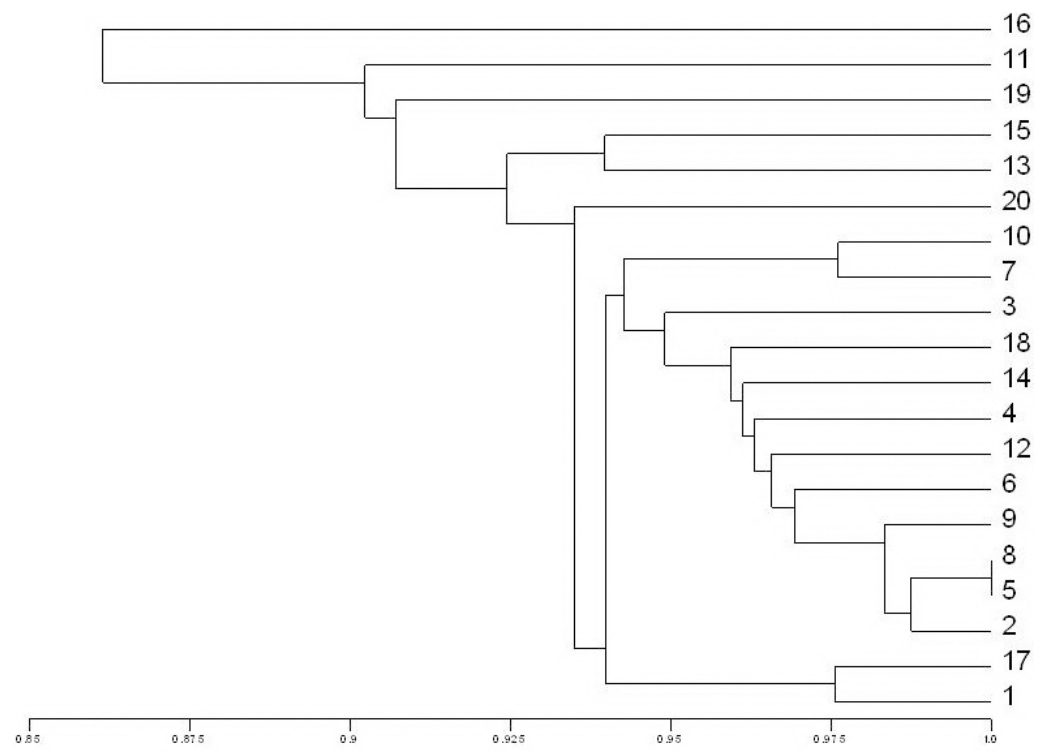

Figure 2. Dendrogram showing the genetic relatedness of 19 eggplant genotypes together with a commercial eggplant cultivar (20) based on the UPGMA cluster analysis of 11 random amplified polymorphic DNA primer data. 


\section{DISCUSSION}

The present study revealed the genetic diversity within a collection of eggplant germplasm representing different geographical regions of Turkey, using molecular (SSR and RAPD markers) approaches (Figures 1 and 2).

Assessment of genetic variability within a germplasm is of interest for practical applications such as the conservation of genetic resources and for breeding purposes, to predict the ability to combine or to rapidly verify the breeding material. Hence, it is crucial for genetic improvement and elite gene exploitation, such as tolerance genes against abiotic stresses. For breeding, it is necessary to detect polymorphisms among cultivars and lines. However, in solanaceous plants, a low frequency of polymorphism among cultivars and intraspecific lines has been reported (Smulders et al., 1997; Nunome et al., 2003; Stàgel et al., 2008), probably due to its autogamous nature.

Genomic SSRs selected on the basis of high polymorphism information content $\mathrm{Nu}$ nome et al., 2009) successfully helped discriminate genotypes in the present study. Successful amplifications of expected sizes were obtained. The genetic similarity estimated according to SSR data was scaled between 0.15 and 1 , suggesting the potential of SSR markers in discriminating among plants of close or distant genetic backgrounds.

Few studies are available in eggplants using RAPD markers for different approaches such as mapping of specific characters of resistance and fruit quality. However, many reports are available in different plant species, demonstrating the potential of RAPD markers in discriminating among plants of different genetic backgrounds and for varietal or cultivar identification (İlbi, 2003). In the present study, the genetic similarity among genotypes was calculated as being between 0.85 and 1 , also emphasizing the power of SSR markers in detecting polymorphisms. However, it must also be noted that the polymorphism obtained by the RAPD markers used was low $(<50 \%)$ except of $O P B 07$, which produced the greatest number of bands and showed the greatest potential to discriminate polymorphic DNA segments. Prior identification of more polymorphic RAPD markers may provide a better characterization of genotypes.

\section{REFERENCES}

Bindler G, van der Hoeven R, Gunduz I, Plieske J, et al. (2007). A microsatellite marker based linkage map of tobacco. Theor. Appl. Genet. 114: 341-349.

Bowcock AM, Ruiz-Linares A, Tomfohrde J, Minch E, et al. (1994). High resolution of human evolutionary trees with polymorphic microsatellites. Nature 368: 455-457.

Doğanlar S, Frary A, Daunay MC, Lester RN, et al. (2002). A comparative genetic linkage map of eggplant (Solanum melongena) and its implications for genome evolution in the Solanaceae. Genetics 161: 1697-1711.

FAO (2008). Food and Agriculture Organization of the United Nations (FAO). FAOSTAT, Italy. [http://faostat.fao.org]. Accessed June 2, 2010.

Frary A, Xu Y, Liu J, Mitchell S, et al. (2005). Development of a set of PCR-based anchor markers encompassing the tomato genome and evaluation of their usefulness for genetics and breeding experiments. Theor. Appl. Genet. 111: 291-312.

$\mathrm{He}$ C, Poysa V and Yu K (2003). Development and characterization of simple sequence repeat (SSR) markers and their use in determining relationships among Lycopersicon esculentum cultivars. Theor. Appl. Genet. 106: 363-373.

İlbi H (2003). RAPD markers assisted varietal identification and genetic purity test in pepper, Capsicum annuum. Sci. Hort. 97: 211-218.

Isshiki S, Okubo and Fujieda K (1994). Phylogeny of eggplant and related Solanum species constructed by allozyme variation. Sci. Hort. 59: 171-176.

Isshiki S, Iwata N and Khan MR (2008). ISSR variations in eggplant (Solanum melongena L.) and related Solanum species. Sci. Hort. 117: 186-190. 
Kalloo G (1993). Eggplant Solanum melongena L. In: Genetic Improvement of Vegetable Crop (Kalloo G and Bergh BO, eds.). Pergamon Press, Oxford, 587-604.

Leal AA, Mangolin CA, do Amaral ATJ, Goncalves LS, et al. (2010). Efficiency of RAPD versus SSR markers for determining genetic diversity among popcorn lines. Genet. Mol. Res. 9: 9-18.

Lefort F, Lally M, Thompson D and Douglas GC (1998). Morfological traits microsatellite fingerprinting and genetic relatedness of a stand of elite oaks $(Q$. robur L.) at Tuallynally, Ireland. Silvae Genet. 47: 5-6.

Mace ES, Lester RN and Gebhardt CG (1999). AFLP analysis of genetic relationships among the cultivated eggplant, Solanum melongena L., and wild relatives. Theor. Appl. Genet. 99: 626-633.

Minch E, Ruiz-Linares A, Goldstein DB, Feldman M, et al. (1995). Microsat (Version 1.4d): a Computer Program for Calculating Various Statistics on Microsatellite Allele Data. Stanford University Medical Center, Stanford.

Nunome T, Ishiguro K, Yoshida T and Hirai M (2001). Mapping of fruit shape and color development traits in eggplant (Solanum melongena L.) based on RAPD and AFLP markers. Breed. Sci. 51: 19-26.

Nunome T, Suwabe K, Iketani H and Hirai M (2003). Identification and characterization of microsatellites in eggplant. Plant Breed. 122: 256-262.

Nunome T, Negoro S, Kono I, Kanamori H, et al. (2009). Development of SSR markers derived from SSR-enriched genomic library of eggplant (Solanum melongena L.). Theor. Appl. Genet. 119: 1143-1153.

Özkaya O and Dündar Ö (2009a). Response of 1-methylcyclopropene (1-MCP) treatments on some quality parameters of plum during storage. J. Food Agric. Environ. 7: 233-236.

Özkaya O and Dündar Ö (2009b). Chemical and physical characteristics of four strawberry cultivars. Asian J. Chem. 21: 2185-2188.

Paetkau D, Calvert W, Stirling I and Strobeck C (1995). Microsatellite analysis of population structure in Canadian polar bears. Mol. Ecol. 4: 347-354.

Rohlf FJ (1988). NTSYS-PC Numerical Taxonomy and Multivariate Analysis System. Exeter Publishing, New York.

Saker MM, Youssef SS, Abdallah NA and Bashandy HS (2005). Genetic analysis of some Egyptian rice genotypes using RAPD, SSR and AFLP. Afr. J. Biotechnol. 4: 882-890.

Sarıkamış G, Marquez J, Maccormack R and Bennett R (2006). High glucosinolate broccoli - A delivery system for sulforaphane. Mol. Breed. 18: 219-228.

Sarıkamış G, Yasar F, Bakir M, Kazan K, et al. (2009). Genetic characterization of green bean (Phaseolus vulgaris) genotypes from eastern Turkey. Genet. Mol. Res. 8: 880-887.

Sarıkamış G, Yanmaz R, Ermis S, Bakir M, et al. (2010). Genetic characterization of pea (Pisum sativum) germplasm from Turkey using morphological and SSR markers. Genet. Mol. Res. 9: 591-600.

Sefe KM, Lefort F, Grando MS and Scott KD (2001). Microsatellite Markers for Grapevine: A State of the Art. In: Molecular Biology and Biotechnology of the Grapevine (Roubelakis-Angelakis KA, ed.). Kluwer Academic Publishers, The Netherlands, 1-29.

Smulders MJM, Bredemeijer G, Rus-Kortekaas W and Aren P (1997). Use of short microsatellites from database sequences to generate polymorphisms among Lycopersicon esculentum cultivars and accessions of other Lycopersicon species. Theor. Appl. Genet. 97: 264-272.

Sneath PH and Sokal RR (1973). Numerical Taxonomy. Freeman, San Francisco.

Stàgel A, Portis E, Toppino L, Rotino GL, et al. (2008). Gene-based microsatellite development for mapping and phylogeny studies in eggplant. BMC Genomics 9: 357.

Wagner HW and Sefc KM (1999). Identity1.0. Centre for Applied Genetics. University of Agricultural Science, Vienna. Weijun (1992). Inheritance of isozymes and morphological characters in the brinjal eggplant. Acta Genet. Sin. 19: 423-429.

Yi GB, Lee JM, Lee S, Choi D, et al. (2006). Exploitation of pepper EST-SSRs and an SSR-based linkage map. Theor. Appl. Genet. 114: 113-130. 